\title{
Inhibition of fertility in mice by passive immunization with antibodies to isolated zonae pellucidae
}

\author{
A. G. Sacco \\ Wayne State University School of Medicine, Department of Gynecology and Obstetrics, \\ The C. S. Mott Center for Human Growth and Development, 275 East Hancock Avenue, \\ Detroit, Michigan 48201, U.S.A.
}

\begin{abstract}
Summary. A chromatographically purified preparation of gamma globulin produced against isolated zonae pellucidae of mice was used to immunize mice. A single 2.5 mg dose totally inhibited fertility for a minimum of 11 days.
\end{abstract}

\section{Introduction}

The zona pellucida contains a specific antigen(s) currently being investigated for immunocontraceptive purposes (Shivers, 1977). The present report is a further assessment of the effect on fertility of passive immunization with antibodies against the zona. It differs significantly from previous reports by utilizing chromatographically purified gamma globulin prepared from antisera produced against isolated zonae and a passive immunization regimen involving spontaneous matings.

\section{Materials and Methods}

Eggs were obtained from Sch:ARS(CF1)f outbred mice following established procedures for inducing superovulation. Mechanically isolated zonae were prepared as previously described (Sacco \& Palm, 1977). The antiserum against the zonae was produced in 2 rabbits which received 2588 and 3200 zonae respectively (Vaitukaitis, Robbens, Nieschag \& Ross, 1971).

Anti-zona activity was tested by observing the antibody-produced precipitate on the zona surface and/or by the indirect fluorescent antibody technique following published procedures (Sacco, 1977a, b). Tissue specificity was verified by immunodiffusion methods involving 17 mouse tissues (Sacco, 1977a, b) and by immunofluorescent reaction against mouse cornea and cartilage (Sacco \& Shivers, 1973).

Antiserum ( $30 \mathrm{ml}$ volumes) was rendered specific to mouse zonae by absorption with freezedried mouse plasma $(30 \mathrm{mg} / \mathrm{ml})$ and spleen $(0.4 \mathrm{~g} / \mathrm{ml})$. The effectiveness of the absorptions was verified by double diffusion analyses. Gamma globulin fractions of absorbed antiserum were prepared by DEAE cellulose chromatography (Fahey \& Terry, 1973). Only purified gamma globulin fractions were used for passive immunization.

Passive immunizations were initially carried out on hormonally primed mice to determine the correct gamma globulin dose for spontaneous matings. Single injections of gamma globulin were given intraperitoneally 28-30 h after PMSG. Doses tested ranged from 0.5 to $3.0 \mathrm{mg} / \mathrm{mouse}$. Females injected with saline $(8.5 \mathrm{~g} \mathrm{NaCl} / \mathrm{l})$ served as controls. Immunized mice were mated after the hCG injection and examined for copulatory plugs the next morning. All mice were killed $24 \mathrm{~h}$ later and their reproductive tracts were flushed. All eggs and embryos were observed for the zona precipitate and those not demonstrating this layer were tested by the fluorescent antibody method. For some mice, ovarian eggs were similarly examined. 
A second group of mice were allowed to mate spontaneously after passive immunization with $2.5 \mathrm{mg}$ gamma globulin/mouse. Controls consisted of mice injected with saline $(8.5 \mathrm{~g} \mathrm{NaCl} / \mathrm{l})$, preimmune gamma globulin, and preimmune gamma globulin previously 'absorbed' with plasma and spleen. Mice were injected at random stages of the oestrous cycle and were checked daily for copulatory plugs. Most mice were killed at Days 16-18 of gestation and fetuses and/or implantation sites were noted but the pregnancies in 6 gamma globulin-injected mice were allowed to go to term and the mice remated.

\section{Results}

All bleedings produced a dense precipitation layer on the mouse zona but the antiserum was not monospecific for zona since immunodiffusion studies demonstrated single precipitin bands between the antiserum and mouse brain, duodenum, liver, ovary, plasma, spleen and serum. An absorption regimen involving plasma and spleen was required to obtain monospecific anti-zona serum. Purified gamma globulin preparations of this absorbed antiserum (Pl. 1, Fig. 1) produced the zona precipitate to a titre of $32(125 \mu \mathrm{g}$ protein $/ \mathrm{ml})$ and bound to the zona, as determined by fluorescent techniques, to a titre of $256(15.6 \mu \mathrm{g}$ protein $/ \mathrm{ml})$.

Table 1 summarizes the results of passive immunization of mice with various doses of antizona gamma globulin. Antibody was detected by fluorescence (Pl. 1, Fig. 2) on all zonae regardless of dose given. Findings concerning the presence and intensity of the precipitation layer varied. Zonae from mice immunized with $0.5 \mathrm{mg}$ gamma globulin never possessed the precipitate. For mice immunized with higher doses, results varied, from the precipitate being completely absent to being present as a dense layer. Varied responses concerning precipitate

\section{PLATE I}

Fig. 1. Unfertilized mouse egg treated with chromatographically purified plasma-spleen absorbed anti-zona pellucida gamma globulin $(2 \mathrm{mg} / \mathrm{ml})$. Note dense precipitate on outer surface of zona (arrow). $\times 1230$.

Fig. 2. Isolated zonae of eggs obtained from mated mouse passively immunized with $2.0 \mathrm{mg}$ anti-zona gamma globulin and tested approximately $66 \mathrm{~h}$ later for antibody binding by the indirect fluorescent antibody technique. Saline-injected mice served as controls (C). Strong to moderate fluorescence was present although no precipitate was observed on zonae from this mouse. $\times 320$.

Fig. 3. Unfertilized eggs from mated mouse passively immunized with $2.0 \mathrm{mg}$ anti-zona gamma globulin which demonstrate variations in intensity of the zona precipitate. Two-cell embryos are from control mouse injected with saline and do not possess a precipitate on the zona. Thick arrow $=$ dense precipitate, thin arrow $=$ moderate precipitate, double arrows $=$ faint precipitate. $\times 310$.

Fig. 4. Reproductive tracts of mated mice passively immunized with $2.5 \mathrm{mg}$ purified plasmaspleen absorbed anti-zona gamma globulin (right) and $2.5 \mathrm{mg}$ preimmune gamma globulin (left) and killed on Day 18 of gestation. Control mouse (left) had 12 normal fetuses while antibodyimmunized mouse showed no evidence of pregnancy.

Fig. 5. Ovarian eggs obtained at Day 18 of gestation from anti-zona gamma globulinimmunized mouse demonstrating non-uniform appearance of precipitate on zona. Arrows indicate regions where precipitate is present. Compare to precipitate on zona in Fig. 1. Control ovarian egg (lower right) is from spontaneously mated mouse immunized with preimmune gamma globulin. $\times 1160$.

Fig. 6. Ovarian eggs obtained at Day 18 of gestation from anti-zona gamma globulinimmunized mouse and tested for antibody binding to zona by the indirect fluorescent antibody method. Note variations in intensity of fluorescence among zonae. Zonae on eggs from control mice $(C)$ immunized with preimmune gamma globulin did not fluoresce. $\times 320$. 
PLATE 1
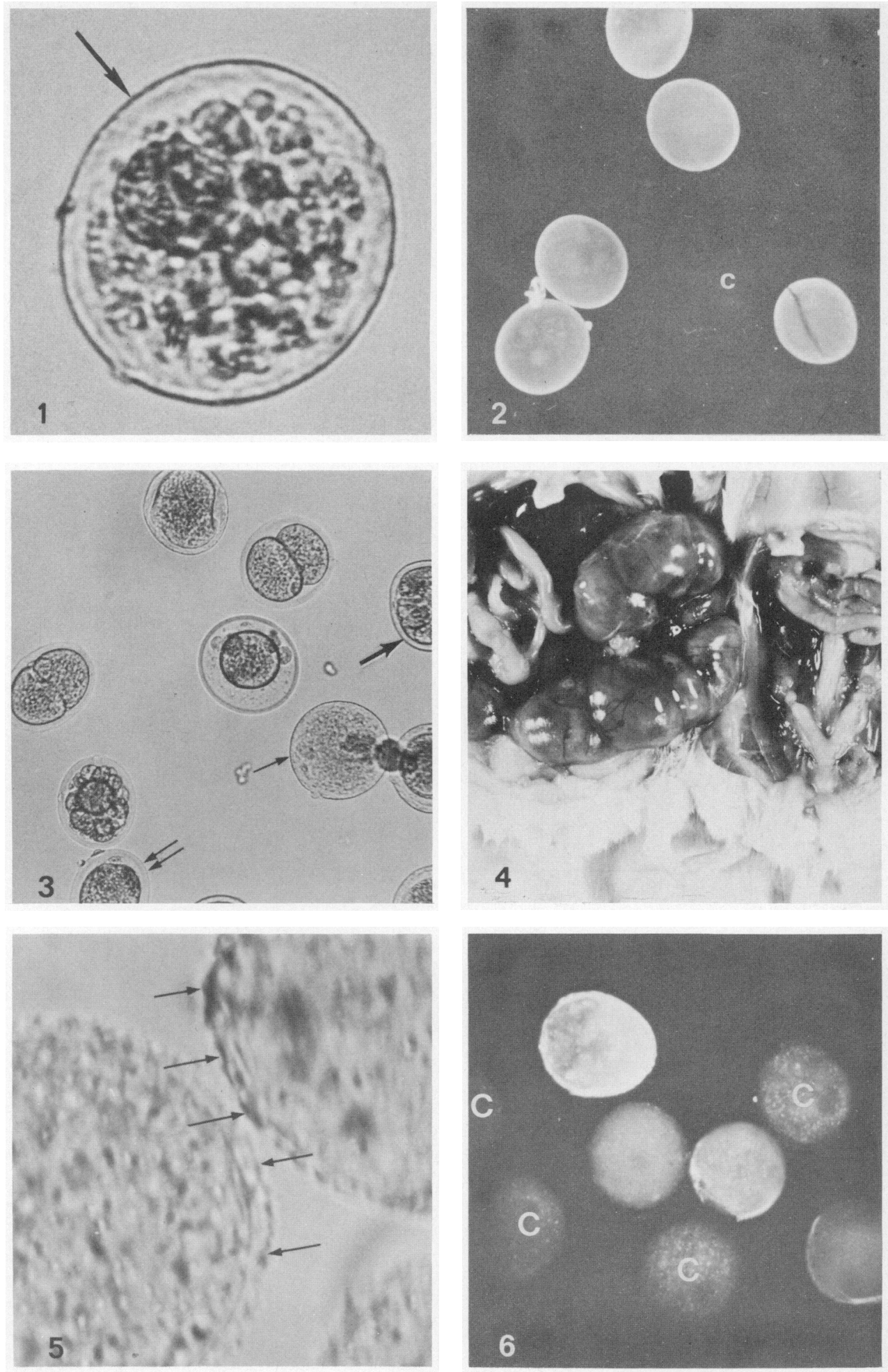

(Facing p. 534) 
Table 1. Passive immunization of mice with various doses of purified anti-zona gamma globulin and effect on fertilization

\begin{tabular}{|c|c|c|c|c|c|c|}
\hline \multirow{3}{*}{$\begin{array}{c}\text { Dosage } \\
(\mathrm{mg})\end{array}$} & \multirow{3}{*}{$\begin{array}{l}\text { No. of mice } \\
\text { immunized }\end{array}$} & \multicolumn{5}{|c|}{ Eggs examined } \\
\hline & & \multicolumn{2}{|c|}{ From all mice } & \multicolumn{3}{|c|}{ From mated mice } \\
\hline & & Total & Ppt. layer & Total & Ppt. layer & Fertilized (\%) \\
\hline 0 & 8 & 384 & - & 299 & - & $257 / 299(86)$ \\
\hline 0.5 & 2 & 44 & - & 0 & N.A. & N.A. \\
\hline 1 & 3 & 112 & - to +++ & 7 & - & $7 / 7(100)$ \\
\hline $1 \cdot 5$ & 6 & 335 & - to +++ & 184 & - to +++ & $51 / 184(28)$ \\
\hline 2 & 18 & 779 & - to +++ & 392 & - to +++ & $0 / 392(0)$ \\
\hline $2 \cdot 5$ & 2 & 78 & + to +++ & 72 & +++ & $0 / 72(0)$ \\
\hline 3 & 1 & 24 & - to +++ & 0 & N.A. & N.A. \\
\hline Totals & 40 & 1756 & & 954 & & \\
\hline
\end{tabular}

N.A. $=$ not applicable; Ppt. $=$ precipitation $(-=$ none $+=$ faint $;++=$ moderate $;+++=$ dense $)$.

intensity were frequently observed on zonae obtained from the same female, regardless of the dose received (Pl. 1, Fig. 3).

Eggs from mice immunized with $1 \mathrm{mg}$ doses were fertilizable (Table 1) although fluorescent methods demonstrated antibody bound to zona. Immunization with $1.5 \mathrm{mg}$ doses produced an inhibitory effect, as evidenced by a $28 \%$ fertilization rate compared with $86 \%$ for the controls. Fertilized eggs from females immunized with 1 or $1.5 \mathrm{mg}$ anti-zona gamma globulin did not possess the zona precipitate. Doses of $2 \mathrm{mg}$ or more completely inhibited fertility although some eggs from these mice did not possess the zona precipitate.

Table 2 summarizes fertility results after passive immunization with $2.5 \mathrm{mg}$ anti-zona gamma globulin. Complete inhibition of fertility was obtained (Pl. 1, Fig. 4) in contrast to controls of which $100 \%$ immunized with saline and preimmune serum absorbed with plasma and spleen, and $75 \%$ immunized with unabsorbed preimmune serum became pregnant. Average litter sizes for control groups were $12.4,11.8$ and 11.7 fetuses respectively.

Ovarian eggs obtained at Days 16-18 of gestation from antibody-injected and spontaneously mated mice possessed the zona precipitate. However, it no longer appeared uniform in density (Pl. 1, Fig. 5) and the intensity of fluorescence also varied between zonae (Pl. 1, Fig. 6).

Table 2. Inhibition of fertility in spontaneously mating mice following passive immunization with antizona pellucida gamma globulin

\begin{tabular}{lccccc}
\hline \multicolumn{1}{c}{ Treatment } & $\begin{array}{c}\text { No. of } \\
\text { mice }\end{array}$ & $\begin{array}{c}\text { Dose } \\
(\mathrm{mg})\end{array}$ & $\begin{array}{c}\text { Days between } \\
\text { immunization } \\
\text { and mating } \\
\text { (mean) }\end{array}$ & $\begin{array}{c}\text { No. of mice } \\
\text { pregnant/no. } \\
\text { immunized }\end{array}$ & $\begin{array}{c}\text { Mean } \\
\text { litter } \\
\text { size }\end{array}$ \\
\hline $\begin{array}{l}\text { Saline } \\
\text { Preimmune serum }\end{array}$ & 10 & 0 & $1-6(2 \cdot 9)$ & $10 / 10$ & 12.4 \\
$\begin{array}{l}\text { Preimmune serum } \\
\text { (absorbed with plasma and spleen) }\end{array}$ & 20 & $2 \cdot 5$ & $1-15(3 \cdot 7)$ & $15 / 20$ & $11 \cdot 7$ \\
$\begin{array}{l}\text { Antiserum } \\
\text { (absorbed with plasma and spleen) }\end{array}$ & 5 & 2.5 & $1-6(3.5)$ & $5 / 5$ & $11 \cdot 8$ \\
\hline
\end{tabular}

* Determined at Days $16-18$ of gestation for $22 / 28$ mice. Remaining 6 mice were allowed to give birth (see Table 3). 
Table 3. Return of fertility in mice after a single injection of $2.5 \mathrm{mg}$ anti-zona pellucida gamma globulin

\begin{tabular}{cccccc}
\hline & \multicolumn{2}{c}{ 1st pregnancy } & & \multicolumn{2}{c}{ 2nd pregnancy } \\
\cline { 2 - 3 } \cline { 6 - 7 } Mouse & $\begin{array}{c}\text { Days between } \\
\text { immunization } \\
\text { and mating }\end{array}$ & $\begin{array}{c}\text { No. of } \\
\text { young }\end{array}$ & & $\begin{array}{c}\text { Days between } \\
\text { immunization } \\
\text { and mating }\end{array}$ & $\begin{array}{c}\text { No. of } \\
\text { young }\end{array}$ \\
\hline 1 & 1 & 0 & & 27 & 0 \\
2 & 1 & 0 & & 33 & 0 \\
3 & 1 & 0 & & 24 & 9 \\
4 & 3 & 0 & & 24 & 10 \\
5 & 4 & 0 & & 36 & 10 \\
6 & 5 & 0 & & 41 & 12 \\
\hline
\end{tabular}

Zonae from ovarian eggs from hormonally primed mice all possessed uniformly dense zona precipitates and strong fluorescence.

Table 3 demonstrates that the infertility produced by immunization with $2.5 \mathrm{mg}$ anti-zona gamma globulin is temporary. From 6 immunized mice which failed to produce offspring following the first successful mating, 4 became pregnant and delivered normal offspring after a second mating.

\section{Discussion}

At some doses, purified anti-zona gamma globulin totally inhibits fertility in the mouse (Tables 1 and 2), thus confirming earlier reports (Jilek \& Pavlok, 1975; Tsunoda \& Sugie, 1977) in which less purified reagents were used.

The infertility is reversible (Table 3 ) with a single $2.5 \mathrm{mg}$ dose being $100 \%$ effective for at least 11 days (Table 2) and, perhaps in some instances, as long as 33 days (Table 3). This duration of total infertility is comparable to that reported by others (Oikawa \& Yanagimachi, 1975; Yanagimachi, Winkelhake \& Nicolson, 1976) for the hamster.

The observations concerning variations in presence and intensity of the antibody-produced zona precipitate, on zonae obtained from the same mouse (Pl. 1, Fig. 3) and after immunization with various doses of purified gamma globulin (Table 1), indicate that a visible zona precipitate need not be present for inhibition of fertilization to occur. Likewise, these findings also show that the mere association of zona antibody to zona, as detected by fluorescence, does not automatically imply that the zona is impenetrable to spermatozoa and the egg cannot be fertilized. The critical concentration of zona gamma globulin necessary to inhibit fertilization therefore appears to be at a level detectable by fluorescence but below that required to produce a visible precipitate.

Ovarian eggs obtained from hormonally primed mice and observed 2-3 days after passive immunization possessed uniformly dense zona precipitates while those obtained from spontaneously mated mice and observed 18-28 days following immunization possessed an irregular precipitate, thus suggesting a gradual breakdown in the zona precipitate. While it is generally believed that the return of fertility in immunized animals is due to maturation, ovulation and fertilization of eggs with unaffected zonae, this gradual breakdown in the precipitate may also play some role in restoring fertility.

This investigation received financial support from the World Health Organization. 


\section{References}

Fahey, J.L. \& Terry, E.W. (1973) Ion exchange chromatography and gel filtrations. In Handbook of Experimental Immunology, p. 7.1. Ed. D. M. Weir. Blackwell Scientific Publications, Oxford.

Jilek, F. \& Pavlok, A. (1975) Antibodies against mouse ovaries and their effect on fertilization in vitro and in vivo in the mouse. J. Reprod. Fert. 42, 377-380.

Oikawa, T. \& Yanagimachi, R. (1975) Block of hamster fertilization by anti-ovary antibody. J. Reprod. Fert. 45, 487-494.

Sacco, A.G. (1977a) Antigenicity of the human zona pellucida. Biol. Reprod. 16, 158-163.

Sacco, A.G. (1977b) Antigenic cross-reactivity between human and pig zona pellucida. Biol. Reprod. 16, $164-173$.

Sacco, A.G. \& Palm, V.S. (1977) Heteroimmunization with isolated pig zonae pellucidae. J. Reprod. Fert. $51,165-168$.

Sacco, A.G. \& Shivers, C.A. (1973) Localization of tissue-specific antigens in the rabbit ovary, oviduct and uterus by the fluorescent antibody technique. $J$. Reprod. Fert. 32, 415-420.

Shivers, C.A. (1977) The zona pellucida as a possible target in immunocontraception. In Immunological Influence on Human Fertility, pp. 13-24. Academic Press, New York.

Tsunoda, Y. \& Sugie, T. (1977) Inhibition of fertilization in mice by anti-zona pellucida antiserum. Jap. J. Zootech. Sci. 48, 784-785.

Vaitukaitis, J., Robbens, J.B., Nieschag, E. \& Ross, G.T. (1971) A method for producing specific antisera with small doses of immunogen. J. clin. Endocr. Metab. 33, 988-991.

Yanagimachi, R., Winkelhake, J.L. \& Nicolson, G.L. (1976) Immunological block to mammalian fertilization: survival and organ distribution of immunoglobulin which inhibits fertilization in vivo. Proc. natn. Acad. Sci, U.S.A. 73, 2405-2408.

Received 28 September 1978 